\title{
Heavy Metal Content in Water of Resko Lake (North-West Poland)
}

\author{
Piotr Daniszewski ${ }^{1, *}$, Ryszard Konieczny ${ }^{2}$ \\ ${ }^{1}$ Department of Invertebrate Zoology and Limnology, Faculty of Biology, \\ University of Szczecin, 13 Waska Street, 71-415 Szczecin, Poland \\ ${ }^{2}$ Institute of Technological and Life Sciences Falenty, Branch Poznań, \\ 67 Biskupińska Street, 60-463 Poznań, Poland \\ *E-mail address: daniszewski73@gmail.com
}

\begin{abstract}
The present research work deals with the quantification of toxic heavy metals in the water samples collected from Lake of Resko (North-West Poland). While the annual average concentration of Cadmium was calculated as $0.34 \mathrm{ppm}$ in 2008 of the year and $0.28 \mathrm{ppm}$ in 2009 of the year. The values obtained were found to be below the permissible limit of $2.0 \mathrm{ppm}$ set for inland surface water. While the annual average concentration of Chromium was calculated as $1,75 \mathrm{ppm}$ in 2008 of the year and $1.97 \mathrm{ppm}$ in 2009 of the year. Which was very much above the permissible limit of $0.1 \mathrm{ppm}$ set for inland surface water. The observed annual average concentration of Copper in the water was 0.05 ppm in 2008 of the year and $0.06 \mathrm{ppm}$ in 2009 of the year, which was below the permissible limit of $3.0 \mathrm{ppm}$ set for inland surface water. While the annual average concentration of Mercury was calculated as $0.03 \mathrm{ppm}$ in 2008 of the year and $0.04 \mathrm{ppm}$ in 2009 of the year, which was very much above the maximum limit of $0.01 \mathrm{ppm}$ set for inland surface water. The annual average concentration of Nickel in the water samples was observed to be $2.07 \mathrm{ppm}$ in 2008 of the year and $2.09 \mathrm{ppm}$ in 2009 of the year, which is close to the limit of $3.0 \mathrm{ppm}$ set for inland surface water. The annual average concentration of $\mathrm{Pb}$ in the water samples was observed to be $0.07 \mathrm{ppm}$ in 2008 of the year and 0.05 ppm in 2009 of the year, which is above the permissible limit of $0.1 \mathrm{ppm}$ set for inland surface water. The results of the present investigation indicate that the annual average concentration of $\mathrm{Zn}$ in water samples was $3.02 \mathrm{ppm}$ in 2008 of the year and $2.74 \mathrm{ppm}$ in 2009 of the year, which is above the permissible limit of $5.0 \mathrm{ppm}$ set for inland surface water.
\end{abstract}

Keywords: Toxic Heavy Metals; Lake water; Lake of Resko (North-West Poland)

\section{INTRODUCTION}

The development of a business man as well as growing to a transformative processes environment adversely affect the quality of the natural environment, including on the aquatic environment [1-5,16-21,1-47,62-70]. With this in mind, it is an important issue to properly protect water reservoirs and also take action to counter the adverse effects of human activities on the natural environment, including water bodies[1-5,16-21,62-70].

Heavy metal pollution is an ever increasing problem of our lakes [1-8,52-61]. These toxic heavy metals entering in aquatic environment are adsorbed onto particulate matter, 
although they can form free metal ions and soluble complexes that are available for uptake by biological organisms [9-17,22-35,52-57,61].

The increase in residue levels of heavy metal content in water, sediments and biota has resulted in decreased productivity and increase in exposure of humans to harmful substances [61]. Many of these metals tend to remain in the ecosystem and eventually move from one compartment to the other within the food chain [36-46,52-61]. Food chain contamination by heavy metals has become a burning issue in recent years because of their potential accumulation in biosystems through contaminated water, soil, sediment and air [57-61]. Hence in the present investigation, efforts are made to quantify the accumulation of toxic heavy metals in water of Resko Lake of North-West Poland.

The study was carried out with an objective to generate the pollution load data from scientific study so as to gauge the extent of pollution due to toxic heavy metals in the lake water.

\section{EXPERIMENTAL}

Lake Resko (Upper Resko) is located on the territory of Drawsko Lake District. The Resko lake is characterized by the following indicators of morphometric [71]:

- latitude $\mathrm{N} 53^{\circ} 40.7^{\prime}$,

- longitude E $15^{\circ} 57.9^{\prime}$,

- the catchment area - $197,2 \mathrm{~km}^{2}$,

- the water catchment area - Rega,

- the surface of the water mirror is 50.7 hectares,

- height - 145,4 m above sea-level,

- the capacity of $1358,4 . \mathrm{m}^{3}$,

- the maximum depth $-5.0 \mathrm{~m}$,

- the average depth is $2,7 \mathrm{~m}$,

- maximum length $-1610 \mathrm{~m}$,

- maximum width - $1200 \mathrm{~m}$,

- the length of the shoreline $-7200 \mathrm{~m}$,

- development of the shoreline -2.85 ,

- unveiling of the indicator - 18.8 [71].

Research was carried out in the years 2008-2009, in the period from April to October. The water samples collected from different sampling stations were filtered using $(0.45 \mu \mathrm{m}$ pore size) filter paper to remove suspended particles. Filtrates were preserved in polythene bottles. In order to prevent the precipitation of metals $2 \mathrm{~mL}$ nitric acid was added to the filtrate [61].

The samples were concentrated to tenfold on a water bath and subjected to nitric acid digestion [14,42]. About $400 \mathrm{~mL}$ of the sample was transformed into clean glass separating funnel in which $10 \mathrm{~mL}$ of $2 \%$ ammonium pyrrolidine dithiocarbamate, $4 \mathrm{~mL}$ of $0.5 \mathrm{M} \mathrm{HCl}$ and $10 \mathrm{~mL}$ of methyl isobutyl ketone (MIBK) are added $[48,61]$.

The solution in separating funnel was shaken vigorously for $2 \mathrm{~min}$ and was left undisturbed for the phases to separate. 
The MIBK extract containing the desired metals was then diluted to give final volumes depending on the suspected level of the metals [13,61]. The sample solution was then aspirated into air acetylene flame in an atomic absorption spectrophotometer.

The analysis for the majority of the trace metals like Cadmium (Cd), Chromium (Cr), Copper $(\mathrm{Cu})$, Mercury $(\mathrm{Hg})$, Nickel $(\mathrm{Ni})$, Lead $(\mathrm{Pb})$ and Zinc $(\mathrm{Zn})$ was done by Atomic Absorption Spectrophotometer.

\section{RESULTS AND DISCUSSION}

The experimental data on toxic heavy metals in water samples collected along the Resko Lake from the month of April 2008 to October 2009 is presented in Table 1 and 2.

Table 1. Heavy metals content in water samples collected from Resko Lake (April to October 2008).

\begin{tabular}{|c|c|c|c|c|c|c|c|}
\hline $\begin{array}{c}\text { Heavy } \\
\text { Metals } \\
\text { (ppm) }\end{array}$ & $\mathbf{C d}$ & $\mathbf{C r}$ & $\mathbf{C u}$ & $\mathbf{H g}$ & $\mathbf{N i}$ & $\mathbf{P b}$ & $\mathbf{Z n}$ \\
\hline $\begin{array}{c}\text { Apr. } \\
2008\end{array}$ & 0.42 & 1.79 & 0.05 & 0.03 & 2.31 & 0.05 & 2.75 \\
\hline $\begin{array}{c}\text { May } \\
2008\end{array}$ & 0.31 & 1.62 & 0.06 & 0.02 & 2.57 & 0.07 & 2,74 \\
\hline $\begin{array}{c}\text { June } \\
2008\end{array}$ & 0.26 & 1.93 & 0.08 & 0.04 & 2.09 & 0.07 & 3.57 \\
\hline $\begin{array}{c}\text { July } \\
2008\end{array}$ & 0.32 & 1.86 & 0.06 & 0.02 & 1.63 & 0.08 & 3.52 \\
\hline $\begin{array}{c}\text { Aug. } \\
2008\end{array}$ & 0.47 & 1.52 & 0.05 & 0.04 & 1,57 & 0.08 & 2.46 \\
\hline $\begin{array}{c}\text { Sept. } \\
2008\end{array}$ & 0.35 & 1.58 & 0.05 & 0.03 & 2.06 & 0.09 & 3.59 \\
\hline $\begin{array}{c}\text { Oct. } \\
2008\end{array}$ & 0.29 & 1.92 & 0.05 & 0.03 & 2.29 & 0.06 & 2.48 \\
\hline \begin{tabular}{c} 
Average \\
\hline
\end{tabular} & 0.34 & 1.75 & 0.05 & 0.03 & 2.07 & 0.07 & 3.02 \\
\hline
\end{tabular}


Table 2. Heavy metals content in water samples collected from Resko Lake (April to October 2009).

\begin{tabular}{|c|c|c|c|c|c|c|c|}
\hline $\begin{array}{c}\text { Heavy } \\
\text { Metals } \\
\text { (ppm) }\end{array}$ & Cd & $\mathbf{C r}$ & $\mathbf{C u}$ & $\mathbf{H g}$ & $\mathbf{N i}$ & $\mathbf{P b}$ & $\mathbf{Z n}$ \\
\hline $\begin{array}{c}\text { Apr. } \\
2008\end{array}$ & 0.26 & 2.19 & 0.03 & 0.05 & 1.82 & 0.03 & 2.27 \\
\hline $\begin{array}{c}\text { May } \\
2008\end{array}$ & 0.29 & 1.75 & 0.08 & 0.03 & 1.68 & 0.05 & 2,46 \\
\hline $\begin{array}{c}\text { June } \\
2008\end{array}$ & 0.16 & 2.35 & 0.04 & 0.03 & 1.84 & 0.05 & 3.70 \\
\hline $\begin{array}{c}\text { July } \\
2008\end{array}$ & 0.35 & 1.53 & 0.07 & 0.05 & 2.39 & 0.07 & 2.59 \\
\hline $\begin{array}{c}\text { Aug. } \\
2008\end{array}$ & 0.29 & 1.80 & 0.06 & 0.03 & 2,61 & 0.05 & 2.63 \\
\hline $\begin{array}{c}\text { Sept. } \\
2008\end{array}$ & 0.36 & 2.37 & 0.08 & 0.03 & 1.93 & 0.06 & 2.94 \\
\hline $\begin{array}{c}\text { Oct. } \\
2008\end{array}$ & 0.24 & 1.83 & 0.04 & 0.03 & 2.39 & 0.04 & 2.63 \\
\hline \begin{tabular}{c} 
Average \\
\hline
\end{tabular} & 0.28 & 1.97 & 0.06 & 0.04 & 2.09 & 0.05 & 2.74 \\
\hline
\end{tabular}

In the present investigation, it was observed that the maximum concentration of $\mathrm{Cd}$ was $0.47 \mathrm{ppm}$ and the minimum was $0.16 \mathrm{ppm}$ (Table 1 and 2). While the annual average concentration was calculated as $0.34 \mathrm{ppm}$ in 2008 of the year and $0.28 \mathrm{ppm}$ in 2009 of the year. The values obtained were found to be below the permissible limit of $2.0 \mathrm{ppm}$ set for inland surface water [61]. There are a few recorded instances Cadmium poisoning in human beings following consumption of contaminated fishes [61]. Cadmium it is less toxic to plants than $\mathrm{Cu}$, similar in toxicity to $\mathrm{Pb}$ and $\mathrm{Cr}$ [61]. It is equally toxic to invertebrates and fishes $[40,61]$. In aquatic systems, cadmium is most readily absorbed by organisms directly from the water in its free ionic form Cd (II) [5,61].

The acute toxicity of cadmium to aquatic organisms is variable, even between closely related species, and is related to the free ionic concentration of the metal [5,61]. Cadmium interacts with the calcium metabolism of animals [5,61]. In fish it causes lack of calcium (hypocalcaemia), probably by inhibiting calcium uptake from the water [5,61]. Effects of long-term exposure can include larval mortality and temporary reduction in growth $[5,61]$.

In the present investigation, it was observed that the maximum concentration of $\mathrm{Cr}$ was $2.37 \mathrm{ppm}$ and the minimum was $1.52 \mathrm{ppm}$ (Table 1 and 2). While the annual average concentration was calculated as $1,75 \mathrm{ppm}$ in 2008 of the year and $1.97 \mathrm{ppm}$ in 2009 of the year. Which was very much above the permissible limit of $0.1 \mathrm{ppm}$ set for inland surface 
water [61]. For invertebrates and fishes, its toxicity is not much acute [61]. Chromium is generally more toxic at higher temperatures and its compounds are known to cause cancer in humans [49,61]. The toxic effect of Chromium on plants indicate that the roots remain small and the leaves narrow, exhibit reddish brown discoloration with small necrotic blotches [30]. Symptoms of Chromium phytotoxicity include inhibition of seed germination or of early seedling development, reduction of root growth, leaf chlorosis and depressed biomass [50, 61].

From the results it appears that the $\mathrm{Cu}$ content in the lake water was minimum of 0.04 ppm and maximum of $0.08 \mathrm{ppm}$ (Table 1 and 2). The observed annual average concentration of Copper in the water was $0.05 \mathrm{ppm}$ in 2008 of the year and $0.06 \mathrm{ppm}$ in 2009 of the year, which was below the permissible limit of $3.0 \mathrm{ppm}$ set for inland surface water [61]. It is important here to note that Copper is highly toxic to most fishes, invertebrates and aquatic plants than any other heavy metal except mercury [61]. It reduces growth and rate of reproduction in plants and animals [61].

The chronic level of $\mathrm{Cu}$ is $0.02-0.2 \mathrm{ppm}[61,67]$. Aquatic plants absorb three times more Copper than plants on dry lands [61]. Excessive Copper content can cause damage to roots, by attacking the cell membrane and destroying the normal membrane structure, inhibited root growth and formation of numerous short, brownish secondary roots [61,67]. Copper is highly toxic in aquatic environments and has effects in fish, invertebrates, and amphibians, with all three groups equally sensitive to chronic toxicity [29,61]. Copper also causes reduced sperm and egg production in many species of fish [53-56,61,66].

In the present investigation, it was observed that the maximum concentration of $\mathrm{Hg}$ was $0.05 \mathrm{ppm}$ and the minimum was $0.02 \mathrm{ppm}$ (Table 1 and 2). While the annual average concentration was calculated as $0.03 \mathrm{ppm}$ in 2008 of the year and $0.04 \mathrm{ppm}$ in 2009 of the year, which was very much above the maximum limit of $0.01 \mathrm{ppm}$ set for inland surface water [61]. Mercury is generated naturally in the environment from the degassing of the earth's crust from volcanic emissions [61].

The organic form is readily absorbed in the gastrointestinal tract (90-100 \%), lesser but still significant amounts of inorganic mercury are absorbed in the gastrointestinal tract (7-15 \%) [61]. Previous study have reported that Mercury in dissolved form enter the fish through the gills $[15,61]$. Further studies have indicated that inorganic Mercury get adsorbed to the suspended particulate matter and settles down [33 61]. Further gets methylated and ultimately enter the food chain, resulting in bioaccumulation [61].

The monthly concentration of $\mathrm{Ni}$ in the lake water samples was found to be in the range of $1.57 \mathrm{ppm}-2.61 \mathrm{ppm}$ (Table 1 and 2). The annual average concentration of Nickel in the water samples was observed to be $2.07 \mathrm{ppm}$ in 2008 of the year and $2.09 \mathrm{ppm}$ in 2009 of the year, which is close to the limit of $3.0 \mathrm{ppm}$ set for inland surface water [61]. Short-term exposure to Nickel on human being is not known to cause any health problems, but long-term exposure can cause decreased body weight, heart, liver damage and skin irritation [61, 67].

In the present investigation, it was observed that the maximum concentration of $\mathrm{Pb}$ was $0.09 \mathrm{ppm}$ and the minimum was $0.04 \mathrm{ppm}$ (Table 1 and 2). The annual average concentration of $\mathrm{Pb}$ in the water samples was observed to be $0.07 \mathrm{ppm}$ in 2008 of the year and $0.05 \mathrm{ppm}$ in 2009 of the year, which is above the permissible limit of $0.1 \mathrm{ppm}$ set for inland surface water [61]. Acute toxicity generally appears in aquatic plants at concentration of 0.1-5.0 ppm [61, 67]. In plants, it initially results in enhanced growth, but from a concentration of $5 \mathrm{ppm}$ onwards, this is counteracted by severe growth retardation, discoloration and morphological abnormalities [61]. There is an adverse influence on photosynthesis, respiration and other metabolic processes [61]. 
Acute toxicity of Lead in invertebrates is reported at concentration of 0.1-10 ppm [61, 67]. Higher levels pose eventual threat to fisheries resources [61]. A number of studies have investigated effects of prolonged Lead exposure on freshwater fish [61]. These studies report a wide range of effects induced by chronic exposure to elevated Lead concentrations, oocyte growth, including effects on pituitary function, gonadosomatic index [47,61].

In the present study, the monthly concentration of Zinc was in the range of $2.27 \mathrm{ppm}$ to $3.70 \mathrm{ppm}$ (Table 1 and 2). The results of the present investigation indicate that the annual average concentration of $\mathrm{Zn}$ in water samples was $3.02 \mathrm{ppm}$ in 2008 of the year and $2.74 \mathrm{ppm}$ in 2009 of the year, which is above the permissible limit of $5.0 \mathrm{ppm}$ set for inland surface water [61]. Zn may result in ne crosis, chlorosis and inhibited growth of plants $[61,67]$. Previous studies have reported toxic effect of Zinc on some aquatic organisms such as fish [3, 61]. Although there is low toxicity effect of $\mathrm{Zn}$ in man, however, the prolonged consumption of large doses has been reported to show some health complications such as fatigue, dizziness and neutropenia $[28,61]$.

\section{CONCLUSION}

While the annual average concentration of Cadmium was calculated as $0.34 \mathrm{ppm}$ in 2008 of the year and $0.28 \mathrm{ppm}$ in 2009 of the year. The values obtained were found to be below the permissible limit of $2.0 \mathrm{ppm}$ set for inland surface water.

While the annual average concentration of Chromium was calculated as $1,75 \mathrm{ppm}$ in 2008 of the year and $1.97 \mathrm{ppm}$ in 2009 of the year. Which was very much above the permissible limit of $0.1 \mathrm{ppm}$ set for inland surface water.

The observed annual average concentration of Copper in the water was $0.05 \mathrm{ppm}$ in 2008 of the year and $0.06 \mathrm{ppm}$ in 2009 of the year, which was below the permissible limit of $3.0 \mathrm{ppm}$ set for inland surface water. While the annual average concentration of Mercury was calculated as $0.03 \mathrm{ppm}$ in 2008 of the year and $0.04 \mathrm{ppm}$ in 2009 of the year, which was very much above the maximum limit of $0.01 \mathrm{ppm}$ set for inland surface water.

The annual average concentration of Nickel in the water samples was observed to be $2.07 \mathrm{ppm}$ in 2008 of the year and $2.09 \mathrm{ppm}$ in 2009 of the year, which is close to the limit of $3.0 \mathrm{ppm}$ set for inland surface water. The annual average concentration of Lead in the water samples was observed to be $0.07 \mathrm{ppm}$ in 2008 of the year and $0.05 \mathrm{ppm}$ in 2009 of the year, which is above the permissible limit of $0.1 \mathrm{ppm}$ set for inland surface water.

The results of the present investigation indicate that the annual average concentration of Zinc in water samples was $3.02 \mathrm{ppm}$ in 2008 of the year and $2.74 \mathrm{ppm}$ in 2009 of the year, which is above the permissible limit of $5.0 \mathrm{ppm}$ set for inland surface water.

\section{References}

[1] Adams W. J., Kimerle R. A., Barnett J. W. Jr., Environ. Sci. Technol. 26(10) (1992) 1864-1875.

[2] Aghor A., Chemicals make Thane creek the worst polluted waterbody, Daily DNA, August 4, 2007. Mumbai, India, 2007.

[3] Alabaster J. S., Lloyds R., Water quality criteria for freshwater fish, Second edition, Butterworths publication, London 1982, pp. 361. 
[4] Ali N. A., Ater M., Sunahara G. L., Robidoux P. Y., Ecotoxicology and Environmental Safety 57(3) (2004) 363-374.

[5] AMAP. Assessment report: Arctic pollution issues. Arctic Monitoring and Assessment Programme, Oslo 1998.

[6] Baršytė Lovejoy D., Acta Zoologica Lituanica. Hydrobiologia 9(2) (1999) 12-20.

[7] Baldwin D. H., Sandahl J. F., Labenia J. S., Scholz N. L., Environmental Toxicology and Chemistry 22(10) (2003) 2266-2274.

[8] Bradl H., Heavy Metals in the Environment: Origin, Interaction and Remediation, Elsevier/Academic Press, London 2005.

[9] Cai L., Liu G., Rensing C., Wang G., BMC Microbiology 9(4) (2009), doi:10.1186/1471 2180-9-4.

[10] Carlos-Tarres-Guzman M., Moreno-Sanchez R., FEMS Microbiol. Rev. 25(3) (2001) 335-347.

[11] Cervantes C., Campos-Garcia J., Debars S., Gutierrez-Corona F., Loza-Tavera H., Chatterjee J., Chatterjee C., Environ. Pollut. 109(1) (2000) 69-74.

[13] Chen M., Ma L. Q., Soil Science Society of American Journal 65(2) (2001) 491-499.

[14] Clesceri L. S., Standard methods for the examination of Water and waste water. In Arnold, E., Greenbergy, Eaton, A.D. (Eds.): Collection and Preservation of Samples And Metals, pp. 1-27, pp. 1-35, pp.3-11, pp. 3-21, APHA, AWWA, WEF, Washington DC 1998.

[15] Dallinger R., Prosi F., Segner H., Back H., Oecologia. 73(1) (1987) 91-98.

[16] Daniszewski P., Wiadomości Melioracyjne i Łąkarskie 4 (2008) 187-188.

[17] Daniszewski P., Ekologia i Technika 5 (2008) 211-214.

[18] Daniszewski P., Inżynier budownictwa 11 (2009) 81-82.

[19] Daniszewski P., Gaz, Woda i Technika Sanitarna 4 (2009) 34-36.

[20] Daniszewski P., International Letters of Chemistry, Physics and Astronomy 5 (2012) 72-79.

[21] Daniszewski P., International Letters of Chemistry, Physics and Astronomy 5 (2012) 80-87.

[22] Das H. K., Mitra A. K., Sengupta P. K., Hossain A., Islam F., Rabbani G. H., Environment International. 30(3) (2004) 383-387.

[23] Dube B. K., Tewari K., Chatterjee J., Chaterejee C., Chemosphere 53(9) (2003) 1147-1153.

[24] Ember L., Environ. Sci. Tech. 9(13) (1975) 116-121.

[25] Ezeonyejiaku C. D., Obiakor, M. O., Ezenwelu C. O., Online Journal of Animal and Feed Research 1(4) (2011) 130-134.

[26] Gbaruko B. C., Ana G. R. E. E., Nwachukwu J. K., African Journal of Biotechnology 7(25) (2008) 4737-4742. 
[27] Health Organisation, International Programme on Chemical Safety (IPCS), Geneva 1992, Switzerland.

[28] Hess R., Schmid B., J. Paediatr. Haematol./Oncol. 24 (2002) 582-584.

[29] Horne M. T., Dunson W. A., Archives of Environmental Contamination and Toxicology 29(4) (1995) 500-505.

[30] Jha S. K., Chavan S. B., Pandit G. G., Negi B. S., Sadasivan S., Environmental Monitoring and Assessment 76(2) (2002) 249-262.

[31] Kabata-Pendias A., Pendias H., Trace Elements in Soils and Plants. 2nd ed. CRC Press, Boca Raton 1992, pp.365.

[32] Kazi T. G., Arain M. B., Baig J. A., The Science of the Total Environment. 407(3) (2009) 1019-1026.

[33] Kehrig H.A., Malm O., Moreira I., Sci. Tot. Environ. 213(1-3) (1998) 263-271.

[34] Khunyakari R. P., Vrushali T., Sharma R. N., Tare V., Journal of Environmental Biology 22 (2) (2001) 141-144.

[35] Lokhande R. S., Kelkar N., Indian Journal of Environmental Protection 19(9) (1999) 664-668.

[36] Lokhande R. S., Singare P. U., Pimple D. S., Resources and Environment. 1(1) (2011) 13-19.

[37] Lokhande R. S., Singare P. U., Pimple D. S., World Environment 1(1) (2011) 6-13.

[38] Maher W., Batley G. E., Lawrence I., Freshwater Biol. 41(2) (1999) 361-372.

[39] Menounou N., Presley B. J., Arch. Environ. Contam. Toxicol. 45(1) (2003) 11-29.

[40] Moore J. W., Ramamoorthy S., Heavy Metals in Natural Waters: Applied Monitoring and Impact Assessment, Springer-Verlag, New York 1984, pp.28-246.

[41] Neff J. M., Environmental Toxicology and Chemistry 16(5) (1997) 917-927.

[42] Paar A., Microwave Sample Preparation System -Instruction Handbook, Anton Paar $\mathrm{GmbH}$, Austria 1998, pp.128.

[43] Patil D., A lot's fishy about our creek and lake fish. Daily Times of India. March 22, Mumbai 2009, India. Obtained through the Internet:

[44] Pyatt A. J., Pyatt F. B., Pentreath V. W., Invertebr Neurosci. 4(3) (2002) 135-140.

[45] Rai U. N., Tripathi R. D., Kumar N., Glaucocystis nostochinearum ltzigsohn. Chromosphere. 25 (1992) 721-732.

[46] Rozsa K. S., Salanki J., Cell Mol. Neurobiol. 14(6) (1994) 735-754.

[47] Ruby S. M., Hull R., Anderson P., Arch Environ Contam Toxicol. 38(1) (2000) 46-51.

[48] Sachdev S. L., West P. W., Environmental Science \& Technology 4(9) (1970) 749-751.

[49] Saxena D. K., Srivastava K., Singh S., Current Science 94(7) (2008) 901-904.

[50] Sharma D. C., Pant R. C., Journal of Environmental Science and Health. Part A 29(5) (1994) 941-948. 
[51] Sharma R. K., Agrawal M., Marshall F. M., Effects of waste water irrigation on heavy metal accumulation in soil and plants, Paper presented at the National Seminar, Bangalore University, Bangalore 2004, India.

[52] Singare P. U., Interdisciplinary Environmental Review 12(4) (2011) 298-312.

[53] Singare P. U., Lokhande R. S., Bhanage S. V., International Journal of Global Environmental Issues. 11(1) (2011) 79-90.

[54] Singare P. U., Lokhande R. S., Naik K. U., Interdisciplinary Environmental Review 12(3) (2011) 215-230.

[55] Singare P. U., Lokhande R. S., Naik K. U., Interdisciplinary Environmental Review 11(1) (2010) 90-107.

[56] Singare P. U., Mishra R. M., Trivedi M. P., Advances in Analytical Chemistry 2(3) (2012) 14-24.

[57] Singare P. U., Mishra R. M., Trivedi M. P., Frontiers in Science. 2(3) (2012) 28-36.

[58] Singare P. U., Thane lakes high on metal content: Study, Daily Times of India, August 10, 2011. Mumbai, India.

[59] Singare P. U., Trivedi M. P., Mishra R. M., American Journal of Chemistry 2(3) (2012) 171-180.

[60] Singare P. U., Trivedi M. P., Mishra R. M., Science and Technology 2(4) (2012) 87-97.

[61] Singare P. U., Talpade M. S., Dagli D. S., Bhawe V.G., International Letters of Chemistry, Physics and Astronomy 8(2) (2013) 94-104.

[62] Spooner D. R., Maher W., Otway N., Arch. Environ. Contam. Toxicol. 45(1) (2013) 92-101.

[63] Sunderman F. W., Arch Ind. 20(1) (1959) 36-41.

[64] Swamy Y. V., Roy Chaudhury G., Das S. N., Sengupta S., Muduli R., Current Science 91(10) (2006) 1409-1412.

[65] Szucs A., Salanki J., Rozsa K. S., Cell Mol. Neurobiol. 14(6) (1994) 769-780.

[66] Taub Frieda B., Fish 430 lectures (Biological Impacts of Pollutants on Aquatic Organisms), University of Washington College of Ocean and Fishery Sciences, Seattle 2004, WA.

[67] Tiwana N. S., Jerath N., Singh G., Ravleen (Eds.), Heavy metal pollution in Punja Rivers, in Newsletter Environmental Information System (ENVIS), Punjab State Council for Science and Technology, India, 3(1) (2005) 3.

[68] Vymazal J., Algae and Element Cycling in Wetlands. Lewis Pub., Boca Raton 1995, pp. 689.

[69] WHO. Cadmium - environmental aspects. Environmental Health Criteria 135. World

[70] Wright D. A., Welbourn P., Environmental Toxicology, Cambridge University Press, Cambridge 2002, U.K.

[71] Jańczak J., Atlas Polish Lakes 1996, 98-99. 